\title{
Applicability of cone beam computed tomography gray values for estimation of primary stability of dental implants
}

Aplicabilidade dos valores de cinza da tomografia computadorizada de feixe cônico na estimativa da estabilidade primária de implantes dentários

\begin{abstract}
Mahnaz SHEIKHI ${ }^{1}$, Mehdi KARAMI ${ }^{2}$, Somayeh ABBASI ${ }^{3}$, Amirhossein MOADDABI ${ }^{4}$, Parisa SOLTANI ${ }^{5}$
1 - Torabinejad Dental Research Center, Department of Oral and Maxillofacial Radiology, School of Dentistry, Isfahan University of Medical Sciences, Isfahan, Iran.

2 - Department of Radiology, School of Medicine, Isfahan University of Medical Sciences, Isfahan, Iran.

3 - Department of Mathematics, Isfahan (khorasgan) Branch, Islamic Azad University, Isfahan, Iran.

4 - Department of Oral and Maxillofacial Surgery, School of Dentistry, Mazandaran University of Medical Sciences, Sari, Iran.

5 - Department of Oral and Maxillofacial Radiology, Dental Implants Research Center, Dental Research Institute, Isfahan University of Medical Sciences, Isfahan, Iran.
\end{abstract}

\begin{abstract}
Objective: To evaluate the relationship between bone density measured by computed tomography (CT) and cone beam computed tomography (CBCT) (Sirona's Galileos scanner) with primary stability of dental implants. Material and methods: 20 fresh bovine femoral heads were prepared by removal of soft tissue, sectioning of the bone, and placement of markers for location and angulation of implants. Bone density of peri-implant areas was determined preoperatively by CT and CBCT scanning of the prepared bone samples represented by Hounsfield units (HUs) and gray values (GVs), respectively. Then, 60 implants in three sizes (diameter $=4 \mathrm{~mm}$, length $=8,10$, and $12 \mathrm{~mm}$ ) were inserted into the bones and maximum insertion torque (IT) was recorded. Osstell device was also used for determining the implant stability quotient (ISQ) for each implant. Statistical analysis was performed on the data $(\alpha=0.05)$. Results: Mean \pm SD values of GV, $\mathrm{HU}$, and ISQ were $1592.75 \pm 231.82,675.26 \pm 115.38$ and $61.90 \pm 10.14$, respectively. Moreover, the most frequent IT limit was $30-35 \mathrm{Ncm}$ (41.4\%). Significant relationships were observed between $\mathrm{HU}$ and IT, GV and IT, HU and ISQ, GV and ISQ, and IT and ISQ in all implant sizes. Moreover, GV and HU also significantly correlated to each other. Conclusion: Bone density values in CBCT and CT scans are positively associated to primary stability of dental implants. Therefore, GVs obtained from Galileos CBCT scanner can be used for preoperative selection of edentulous sites which allow for better implant stability or locations which require further procedures for enhancing the success rate of dental implants.
\end{abstract}

\section{KEYWORDS}

Computed tomography; Cone beam computed tomography; Dental implant.

\section{RESUMO}

Objetivo: Avaliar a relação entre a densidade óssea medida em imagens de tomografia computadorizada (TC) e tomografia computadorizada de feixe cônico (TCFC) e relacionar com a estabilidade primária de implantes dentários. Material e métodos: Foram utilizadas neste estudo 20 cabeças femorais bovinas frescas, preparadas pela remoção de partes moles, secção do osso e colocação de marcadores para localização e angulação dos implantes. A densidade óssea da área peri-implantar foi determinada no pré-operatório em imagens TC e TCFC das amostras de osso peparado, representadas por unidades Hounsfield (HUs) e valores de cinza (GVs), respectivamente. Em seguida, 60 implantes em três tamanhos (diâmetro $=4 \mathrm{~mm}$, comprimento $=8,10$ e $12 \mathrm{~mm}$ ) foram inseridos nos ossos e o torque máximo de inserção (TI) foi registrado. O dispositivo Osstell também foi usado para determinar o quociente de estabilidade do implante (ISQ) para cada implante. A análise estatística foi realizada nos dados $(\alpha=0,05)$. Resultados: Os valores médios \pm DP de GV, HU e ISQ foram $1592,75 \pm 231,82,675,26 \pm 115,38$ e $61,90 \pm$ 10,14 , respectivamente. Além disso, o limite de TI mais frequente foi 30-35 Ncm (41,4\%). Relações significativas foram observadas entre HU e IT, GV e IT, HU e ISQ, GV e ISQ, e IT e ISQ em todos os tamanhos de implante. Os GV e HU também se correlacionaram significativamente. Conclusão: Os valores da densidade óssea em imagens de TCFC e TC mostram-se positivamente associados para estabilidade primária de implantes dentários. Portanto, os GVs obtidos no Sistema de TCFC (Sirona's Galileos) poderiam ser usados para a seleção pré-operatória de sítios edêntulos que permitam uma melhor estabilidade do implante ou locais que requerem procedimentos adicionais para aumentar a taxa de sucesso dos implantes dentários.

\section{PALAVRAS-CHAVE}

Implante dentário; Tomografia computadorizada; Tomografia computadorizada de feixe cônico. 


\section{INTRODUCTION}

I $\mathrm{n}$ modern dentistry, dental implants are an $\perp$ important treatment option for replacement of missing teeth in order to restore function and esthetics. Primary stability of dental implants is a crucial factor for determining success and treatment planning in implantology [1,2]. Implant insertion torque [3], design and type of implant [4, 5], and bone quality [6] are among main factors that contribute to primary stability of dental implants. One of the most accurate and reproducible methods for assessing implant stability is resonance frequency analysis using Osstell device [7, 8]. The device presents implant stability in any given stage by a numeric value called implant stability quotient (ISQ). Higher ISQ is associated to higher implant stability. Higher insertion torque (IT) of implant is another important indicator for higher primary stability $[9,10]$. IT is also closely related to the recipient bone architecture and quality [11].

Therefore, characteristics of recipient bone are important in preoperative evaluation, treatment planning, and outcome prediction of dental implant treatments. Imaging methods have been widely used in order to obtain characteristics of the recipient bone status. With introduction and application of computed tomography (CT) in dentistry, it has been used for pre- and post-operative sectional imaging in implant treatments [12]. Moreover, researchers have used it for classification of edentulous alveolar bone quality. For instance, Gamble and Norton used Hounsfield units (HU) to classify bone quality of implant recipient sites [13]. Recently, cone beam computed tomography (CBCT) has garnered widespread application in dentistry and implantology due to benefits such as lower radiation does, higher availability, and lower costs compared to CT [14]. CBCT is an excellent modality for measuring dimensions of available bone, determining characteristics of bone trabecula, and evaluating adjacent anatomic landmarks and relationships $[15,16]$; However, while quantitative bone density profile represented by $\mathrm{HU}$ is constant in CT scans, bone density values in CBCT depend on various parameters such as device type, exposure parameters, and positioning $[17,18]$. Researchers have attempted to evaluate the relationship between CBCT gray values (GVs) of recipient bone with success of dental implants. However, they stated that the results must be tested for different CBCT scanners, as CBCT GVs vary with scanner type $[19,20]$. Therefore, the aim of the present study is to evaluate the relationship between bone density measured by CT and CBCT (Sirona's Galileos scanner) with primary stability of dental implants.

\section{MATERIAL AND METHODS}

This study was approved by the Bioethics Committee of Isfahan University of Medical Sciences (ethical approval code: IR.MUI. RESEARCH.REC.1398.085). Based on the calculations from the following formula, a sample size off 20 implants in each size would be able to detect correlation coefficient of 0.68 with alpha of 0.05 and power of $80 \%$.

$$
\begin{gathered}
n=\frac{\left(z_{1-\frac{\alpha}{2}}+z_{1-\beta}\right)^{2}}{d^{2}}+3 \\
n=\frac{(1.96+0.84)^{2}}{d^{2}}+3=\frac{7.84}{d^{2}}+3
\end{gathered}
$$

\section{Preparation of bone samples:}

20 fresh bovine femoral bones were chosen in a wide variety of bone types. Soft tissue was removed and the bones were cut into bony blocks. To indicate the angulation of each implant, a metallic marker was placed with $2 \mathrm{~cm}$ horizontal and $1 \mathrm{~cm}$ vertical distance from the selected bone surface in order to 
avoid metallic artifacts interfering with bone structure. The central point for drilling and implant insertion was marked by light-cured glass ionomer (Figure 1).

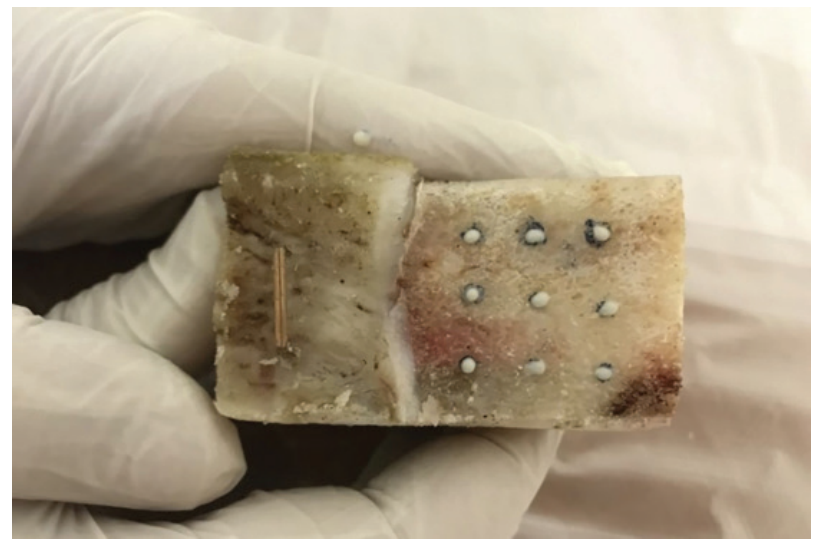

Figure 1 - Bone samples with implant location and angulation markers.

\section{Radiologic examinations and calculations of GV and $\mathrm{HU}$.}

CBCT scanning of the prepared bone samples was performed by Galileos scanner (Sirona, Bensheim, Germany) with exposure parameters of $85 \mathrm{kVP}$ and $21 \mathrm{mAs}$. Also, CT scans were done by General Electric CT scanner (GE Healthcare, Chicago, IL, USA) with exposure parameters of $100 \mathrm{kVP}$ and $150 \mathrm{~mA}$. The resulting DICOM images were imported into Mimics software (version 20, Materialise NV, Leuven, Belgium). Mean GV and $\mathrm{HU}$ was calculated $1 \mathrm{~mm}$ around the determined location of implants in the CBCT and CT images, respectively, as the implant is anchored by being screwed to the surrounding bone [19, 20] (Figure 2).

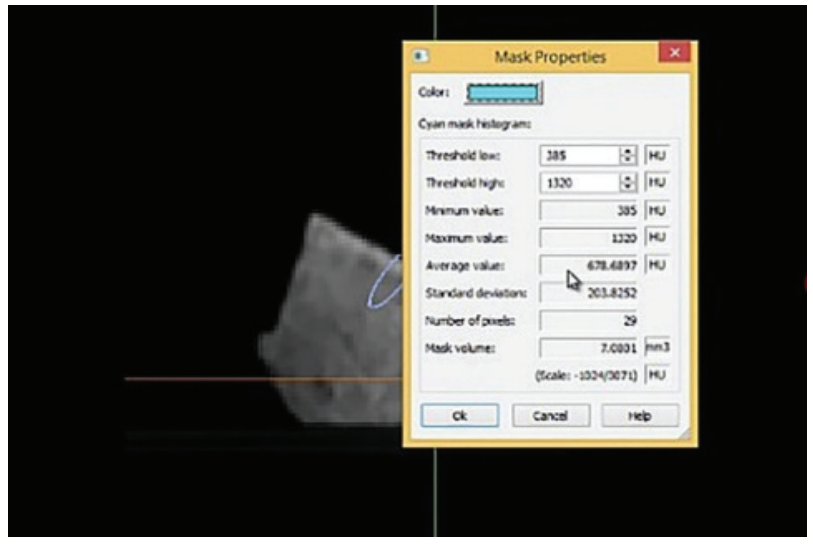

Figure 2 - Bone density value determination around the implant.

Implants, surgical procedures, and IT measurements:

60 implants (Bionic, Nick Kasht Asia, Tehran, Iran) in three sizes (diameter $=$ $4 \mathrm{~mm}$, length $=8,10$, and $12 \mathrm{~mm}) 20$ in each size were used in this study. Implant sockets were prepared with the standard drilling kit according to the manufacturer's instructions [19] and based on angulation and central points provided by metallic and glass ionomer markers, respectively. Then, implants were placed and IT was measured for each implant with the torque wrench. Torque wrench measured the insertion torque in 5 $\mathrm{Ncm}$ accuracy. For instance it shows that the insertion torque is between 20-25 (equal or more than 20 and less than 25).

\section{Resonance frequency analysis:}

Appropriate Smartpegs were mounted on implants and ISQ was measured by Osstell device (Integration Diagnostics, Gothenburg, Sweden) (Figure 3). The measurement was performed in 2 perpendicular directions [21]. The mean value was recorded for further analysis. 


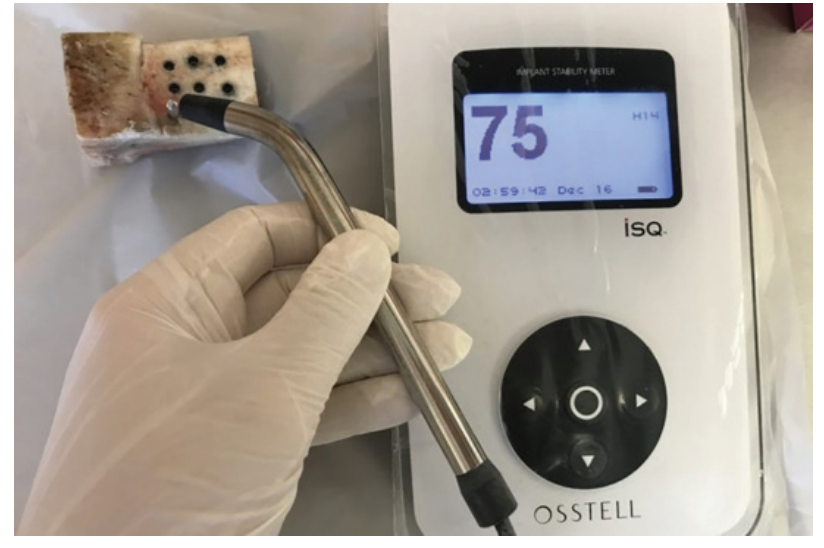

Figure 3 - Determination of implant stability quotient.

\section{Statistical analysis:}

Data was statistically analyzed by Statistical Package for the Social Sciences (SPSS, v. 25, IBM Statistics, NY, USA). Descriptive statistics was performed using minimum, maximum, mean, and standard deviation. One way ANOVA and Kruskal-Wallis tests were used to compare the mean values of independent groups. Pearson and Spearman correlation coefficients were used for evaluating the relationship of quantitative and qualitative data, respectively ( $\alpha=0.05)$.

\section{RESULTS}

After exclusion of two outlier data from further analysis, mean $\pm \mathrm{SD}$ values of $\mathrm{GV}$, $\mathrm{HU}$, and ISQ were $1592.75 \pm 231.82,675.26$ \pm 115.38 and $61.90 \pm 10.14$, respectively. Moreover, the most frequent IT limit was 30-35 $\mathrm{Ncm}$ (41.4\%). Tables I and II present the values of GV, HU, ISQ, and IT in different implant sizes. Significant correlations were found between $\mathrm{HU}$ and IT, GV and IT, HU and ISQ, GV and ISQ, IT and ISQ, and GV and HU (Table III). Figures 3-7 demonstrate the scatter plots of these variables.
Table I - Minimum, maximum and mean values of Hounsfield units, Gray values, and Implant stability quotient in different implant sizes

\begin{tabular}{|ccccccc|c|}
\hline & \multicolumn{2}{c}{ Size } & Number & Minimum & Maximum & Mean \pm SD & P-value \\
\hline \multirow{2}{*}{$\begin{array}{c}\text { Hounsfield } \\
\text { unit }\end{array}$} & $4 \times 8$ & 20 & 483.25 & 841.79 & $672.53 \pm 105.31$ & \\
& $4 \times 10$ & 19 & 472.87 & 798.05 & $697.71 \pm 98.74$ & 0.536 \\
& $4 \times 12$ & 19 & 419.52 & 807.52 & $655.69 \pm 140.48$ & \\
\hline Gray value & $4 \times 10$ & 19 & 1219.60 & 1995.37 & $1627.99 \pm 204.995$ & 0.650 \\
& $4 \times 12$ & 19 & 1183.84 & 1983.37 & $1557.26 \pm 266.11$ & \\
\hline \multirow{2}{*}{$\begin{array}{c}\text { Implant } \\
\text { stability }\end{array}$} & $4 \times 8$ & 20 & 45.50 & 72.50 & $61.30 \pm 8.57$ & \\
quotient & $4 \times 10$ & 19 & 44 & 75 & $63.18 \pm 10.29$ & 0.816 \\
& $4 \times 12$ & 19 & 42 & 75.50 & $61.39 \pm 11.82$ & \\
\hline
\end{tabular}

Table II - Frequency of insertion torque measurements in different implant sizes

\begin{tabular}{|c|c|c|c|c|c|c|c|}
\hline \multirow{3}{*}{$\begin{array}{l}\text { Insertion } \\
\text { torque }\end{array}$} & \multicolumn{6}{|c|}{ Size } & \multirow{3}{*}{ P-value } \\
\hline & \multicolumn{2}{|c|}{$4 \times 8$} & \multicolumn{2}{|c|}{$4 \times 10$} & \multicolumn{2}{|c|}{$4 \times 12$} & \\
\hline & $\begin{array}{l}\text { Fre- } \\
\text { quency }\end{array}$ & $\begin{array}{l}\text { Percent- } \\
\text { age }\end{array}$ & $\begin{array}{l}\text { Fre- } \\
\text { quency }\end{array}$ & $\begin{array}{l}\text { Percent- } \\
\text { age }\end{array}$ & $\begin{array}{l}\text { Fre- } \\
\text { quency }\end{array}$ & $\begin{array}{l}\text { Percent- } \\
\text { age }\end{array}$ & \\
\hline $20-25$ & 2 & 10 & 2 & 10.5 & 5 & 26.3 & 0.698 \\
\hline $25-30$ & 9 & 45 & 6 & 31.6 & 3 & 15.8 & \\
\hline $30-35$ & 8 & 40 & 8 & 42.1 & 8 & 42.1 & \\
\hline $35-40$ & 1 & 5 & 2 & 10.5 & 1 & 5.3 & \\
\hline $40-45$ & 0 & 0 & 1 & 5.3 & 2 & 10.5 & \\
\hline Total & 20 & 100 & 19 & 100 & 19 & 100 & \\
\hline
\end{tabular}

Table III - Correlation table for implant stability quotient, insertion torque, Hounsfield unit, and gray value

\begin{tabular}{|c|c|c|c|c|c|c|}
\hline \multirow[t]{2}{*}{ Variables } & & & $\begin{array}{l}\text { Implant } \\
\text { Stability } \\
\text { quotient }\end{array}$ & $\begin{array}{l}\text { Insertion } \\
\text { torque }\end{array}$ & $\begin{array}{l}\text { Hounsfield } \\
\text { unit }\end{array}$ & Gray value \\
\hline & \multicolumn{6}{|l|}{$\begin{array}{l}\text { Implant } \\
\text { size }\end{array}$} \\
\hline \multirow{3}{*}{$\begin{array}{l}\text { Implant } \\
\text { Stability } \\
\text { quotient }\end{array}$} & $4 \times 8$ & $\begin{array}{c}r \\
\text { p value }\end{array}$ & 1 & & & \\
\hline & $4 \times 10$ & $\begin{array}{c}r \\
\text { p value }\end{array}$ & 1 & & & \\
\hline & $4 \times 12$ & $\begin{array}{c}r \\
\text { p value }\end{array}$ & 1 & & & \\
\hline \multirow{3}{*}{$\begin{array}{l}\text { Insertion } \\
\text { torque }\end{array}$} & $4 \times 8$ & $\begin{array}{c}r \\
\text { p value }\end{array}$ & $\begin{array}{l}0.866 \\
<0.001\end{array}$ & 1 & & \\
\hline & $4 \times 10$ & $\begin{array}{c}r \\
\text { p value }\end{array}$ & $\begin{array}{l}0.903 \\
<0.001\end{array}$ & 1 & & \\
\hline & $4 \times 12$ & $\begin{array}{c}r \\
\text { p value }\end{array}$ & $\begin{array}{c}0.951 \\
<0.001\end{array}$ & 1 & & \\
\hline \multirow{4}{*}{$\begin{array}{l}\text { Houns- } \\
\text { field unit }\end{array}$} & $4 \times 8$ & $\begin{array}{c}r \\
\text { p value }\end{array}$ & $\begin{array}{l}0.662 \\
0.001\end{array}$ & $\begin{array}{l}0.561 \\
0.001\end{array}$ & 1 & \\
\hline & $4 \times 10$ & $r$ & 0.700 & 0.654 & 1 & \\
\hline & $4 \times 10$ & p value & 0.001 & 0.002 & & \\
\hline & $4 \times 12$ & $\begin{array}{c}r \\
\text { pvalue }\end{array}$ & $\begin{array}{c}0.908 \\
<0.001\end{array}$ & $\begin{array}{c}0.792 \\
<0.001\end{array}$ & 1 & \\
\hline \multirow{4}{*}{$\begin{array}{l}\text { Insertion } \\
\text { torque }\end{array}$} & $4 \times 8$ & $\begin{array}{c}r \\
\text { p value }\end{array}$ & $\begin{array}{l}0.585 \\
0.007\end{array}$ & $\begin{array}{l}0.683 \\
0.001\end{array}$ & $\begin{array}{l}0.918 \\
<0.001\end{array}$ & 1 \\
\hline & $4 \times 10$ & $r$ & 0.599 & 0.610 & 0.953 & 1 \\
\hline & $4 \times 10$ & p value & 0.007 & 0.005 & $<0.001$ & \\
\hline & $4 \times 12$ & $\begin{array}{c}r \\
\text { pvalue }\end{array}$ & $\begin{array}{c}0.952 \\
<0.001\end{array}$ & $\begin{array}{c}0.951 \\
<0.001\end{array}$ & $\begin{array}{c}0.861 \\
<0.001\end{array}$ & 1 \\
\hline
\end{tabular}



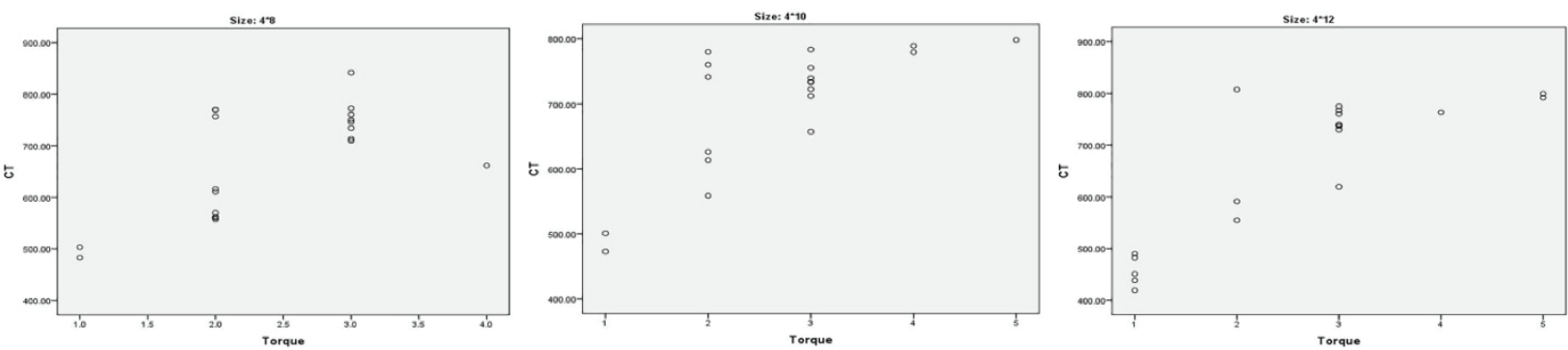

Figure 4 - Scatter plots of density values in CT vs. implant insertion torque in implant size (a) 4×8, (b) 4×10, (c) 4×12.
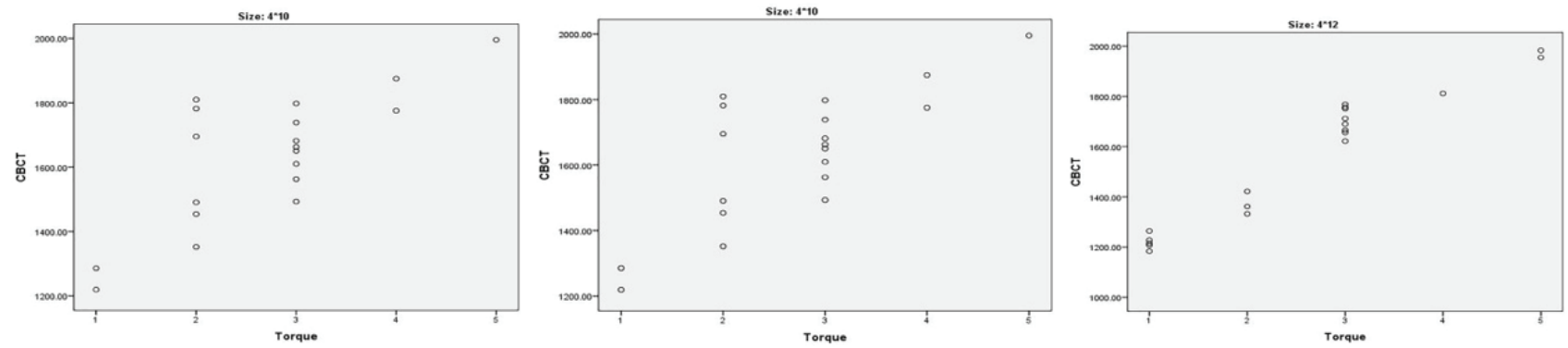

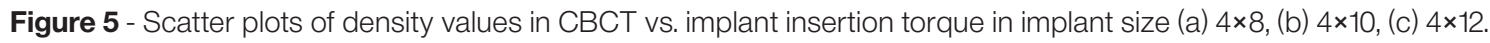
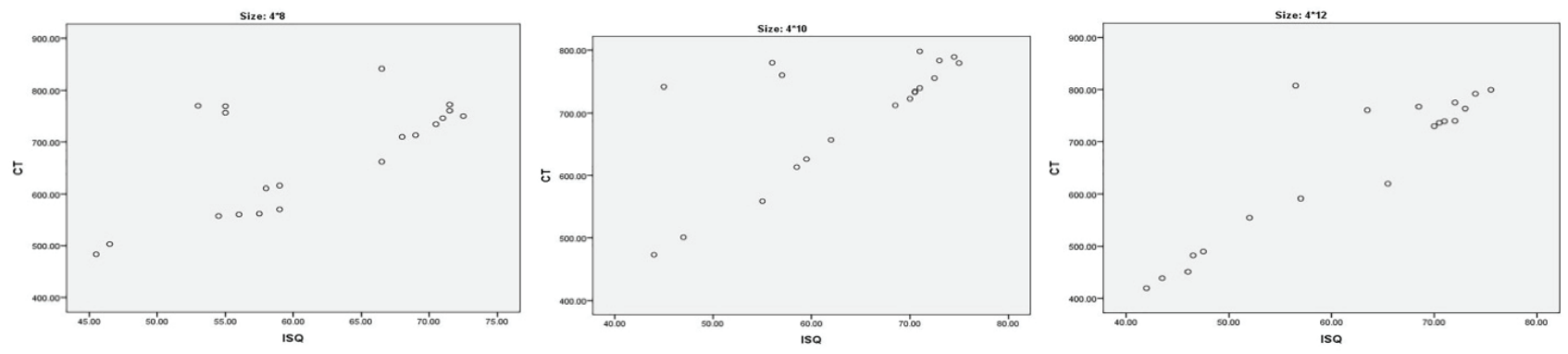

Figure 6 - Scatter plots of density values in CT vs. implant stability quotient in implant size (a) 4×8, (b) 4×10, (c) 4×12.
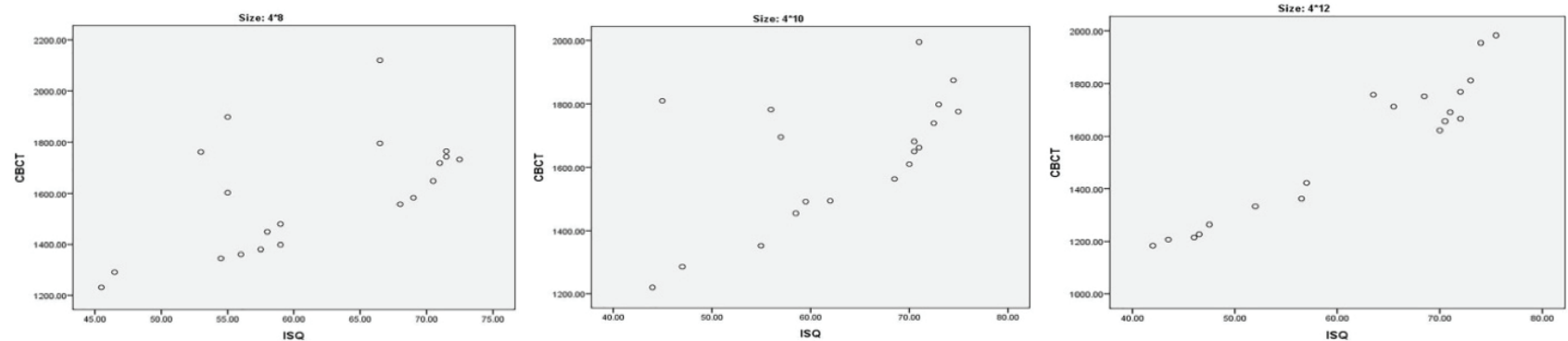

Figure 7 - Scatter plots of density values in CBCT vs. implant stability quotient in implant size (a) 4×8, (b) 4×10, (c) 4×12. 


\section{DISCUSSION}

Prediction of primary stability of dental implants is very important in treatment planning and estimation of treatment duration. Disuse atrophy causes a decrease in mineral density of alveolar bone and this compromised bone is prone to a higher risk for failure of dental implant placement [20]. Therefore, evaluation of bone quality is strongly suggested in pre-operative stage, rather than during or after insertion of dental implants. In this way, suitable locations which provide better stability for implants may be selected preoperatively [18]. This mentioned, attempts have been made to correlate implant stability to GVs obtained by CBCT, which is the primary sectional imaging technique in maxillofacial implantology. Researchers have insisted that results must be tested on different CBCT scanners $[19,20]$. One limitation associated with in-vivo clinical studies on the subject is that the entire surgical process of implant placement cannot be uniformly followed for identical implants. Thus, fresh femoral heads are a good experimental model for implant placement [19].

In an in-vitro study, Isoda et al. [19] found that GVs obtained by Gendex GXB-500 CBCT scanner from the recipient bone are significantly related to IT and ISQ of 18 identical implants. Arisan et al. [20] reported that peri-implant bone density obtained by CT and CBCT (Iluma scanner) has a significant relationship with ISQ and IT of dental implants. However, their study did not address the statistical significance of these relationships in different implant sizes. These findings are generally consistent with the results of the present study. Moreover, the present study is in accordance with studies performed by Pagliani et al. [22], Sennerby et al. [23], and Salimov et al. [24]. Wada et al. [25] in an in-vitro study showed a significant relationship between peri-implant bone GVs obtained by Gendex GXB-500 CBCT scanner and IT of 4 implants in 4 different sizes. However, the relationship between GV and ISQ was only significant in the largest implant. Since, only one implant in each size was used in their study, these results may be subject of sample size error.

In most in-vitro studies performed on the subject, CBCT or CT image acquisition was performed after drilling and preparation of implant sockets. During the preparation of implant socket, peri-implant bone may be altered due to the drilling process. In the present study, CT and CBCT images were obtained prior to drilling procedure, simulating the clinical condition in which patients are referred for imaging in the preoperative stage. Therefore, implant location and angulation markers were placed to represent the future position of implants in CT and CBCT images.

Most CBCT scanners, demonstrate bone density by non-calibrated values, rather than calibrated HUs. Several inherent factors lead to decreased accuracy and reproducibility of GVs in CBCT imaging. One of these factors is scatter radiation produced due to the volumetric nature of CBCT imaging and collected by the area detector. These unwanted signals, decrease the accuracy of pixel values and thus GVs of the scan [23]. Moreover, heel effect and metal artifacts are another source of inaccuracy of the GVs in CBCT scanning [26]. Reconstruction algorithms in CBCT imaging can also affect the uniformity of GVs [18]. However, attempts have been made in order to correlate or calibrate the GVs of different CBCT scanners with corresponding HUs in CT imaging [27-29]. These results are consistent with the findings of the present study that GVs obtained by Galileos CBCT scanners are correlated to HUs. However, these results may need to be confirmed for different CBCT scanners.

\section{CONCLUSION}

Significant relationships were observed between HU and IT, GV and IT, HU and ISQ, 
GV and ISQ, and IT and ISQ in all implant sizes. Moreover, GV and HU also significantly correlated to each other. Therefore, within the limitations of this study, GVs obtained by Galileos CBCT scanner can be used for selection of edentulous sites which allow for better implant stability or locations which require further procedures for enhancing the success rate of dental implants.

\section{Acknowledgment}

This study is based on a thesis submitted to the School of Dentistry, Isfahan University of Medical Sciences, in partial fulfillment of the requirement for the MSC degree.

\section{Funding}

This study was financially supported by Isfahan University of Medical Sciences Research Grant \#398103

\section{Competing interests}

The authors declare that they have no competing interests.

\section{REFERENCES}

1. Lioubavina-HackN, Lang NP, Karring T. Significance of primary stability for osseointegration of dental implants. Clin Oral Implants Res. 2006;17(3):244-50. do: 10.1111/.j.1600-0501.2005.01201.x

2. JavedF, Romanos GE. The role of primary stability for successful immediate loading of dental implants. A literature review. J Dent. 2010;38(8):612-20. doi: 10.1016/j.jdent.2010.05.013

3. Turkyilmaz I.A comparison between insertion torque and resonance frequency in the assessment of torque capacity and primary stability of Brånemark system implants. J Oral Rehabil. 2006;33(10):754-9. doi: 10.1111/.1365-2842.2006.01631.x

4. O'Sullivan D, Sennerby L, Jagger D, Meredith N. A comparison of two methods of enhancing implant primary stability. Clin ImplantDent Relat Res. 2004;6(1):48-57.doi:10.1111/j.1708-8208.2004.tb00027.x

5. Wu S-W, LeeC-C, Fu P-Y, Lin S-C. The effects of flute shape and thread profile on the insertion torque and primary stability of dental implants. Med Eng Phys. 2012;34(7):797-805. doi: 10.1016/.jmedengphy.2011.09.021

6. Hiasa K, Abe Y,Okazaki Y,Nogami K, Mizumachi W, Akagawa Y.Preoperative computed tomography-derived bone densities in Hounsfield units at implant sites acquired primary stability. ISRN Dent 2011;2011. doi:10.5402/2011/678729

7. Zix J, Hug S, Kessler-Liechti G, Mericske-Stern R. Measurement of dental implant stability by resonance frequency analysis and damping capacity assessment: comparison of both techniques in a clinical trial. Int J Oral Maxillofac Implants. 2008;23(3):525-30.
8. ValderramaP, Oates TW, Jones AA, Simpson J, Schoolfield JD, Cochran DL Evaluation of two different resonance frequency devices to detect implant stability: a clinical trial.J Periodontol. 2007;78(2):262-72. doi:10.1902/ jop.2007.060143

9. Farré-Pagès N, Augé-Castro ML, Alaejos-AlgarraF,Mareque-Bueno J, FerrésPadróE, Hernández-Alfaro F. Relation between bone density and primary implant stability. Med Oral Patol Oral Cir Bucal. 2011;16(1):e62-7.doi: 10.4317/ medoral.16.e62

10. Trisi P,Perfetti G,Baldoni E, Berardi D, Colagiovanni M, Scogna G. Implant micromotion is related to peak insertion torque and bone density. Clin Oral Implants Res. 2009;20(5):467-71. doi:10.1111/.j1600-0501.2008.01679.x

11. TurkyilmazI,McGlumphy EA. Influence of bone density on implant stability parameters and implant success: a retrospective clinical study. BMC Oral Health. 2008;8(1):32. doi: 10.1186/1472-6831-8-32

12. Schwarz MS, Rothman SL, Rhodes ML, Chafetz N. Computed tomography: Partl.Preoperative assessment of the mandible for endosseous implant surgery. Int J Oral Maxillofac Implants. 1987;2(3):137-41.

13. Norton MR, Gamble C. Bone classification: an objective scale of bone density using the computerized tomography scan. Clin Oral Implants Res. 2001;12(1):79-84. doi: 10.1034/.1600-0501.2001.012001079.x

14. Scarfe WC, Farman AG, Sukovic P.Clinical applications of cone-beam computed tomography in dental practice. J Can Dent Assoc. 2006;72(1):75.

15. de Castro Lopes SLP, da Costa Donato ISQ, de Assis ACS, de Moraes MEL, Manhães Jr LRC, de Oliveria Gamba T. Anatomic characterization of mentual foramen in dentate and edentulous regions with Cone Beam Computed Tomography (CBCT). Braz Dent Sci. 2016;19(4):49-55. doi:10.14295/bds.2016. v19i4.1305

16. de Castro Lopes SLP,Moraes MEL, Júnior LRCM, de Assis ACS, Giosa DT, Urbano DS. Incidental findings of bone alterations in temporomandibular joints in cone-beam computed tomography scans adquired for implants planning: the importance of complete field of view analysis. Braz Dent Sci. 2016;19(2):1824. doi: 10.14295/bds.2016.v19i2.1243

17. Nackaerts 0 , Maes F, Yan H, Souza PC, Pauwels R, Jacobs R. Analysis of intensity variability in multislice and cone beam computed tomography. Clin Oral Implants Res. 2011,22(8):873-9. doi:10.1111/j.1600-0501.2010.02076.x

18. Pauwels R, Jacobs R, Singer SR, Mupparapu M. CBCT-based bone quality assessment: are Hounsfield units applicable? Dentomaxillofac Radiol. 2014:44(1):20140238. doi: 10.1259/dmfr.20140238

19. Isoda K, Ayukawa Y, Tsukiyama Y, Sogo M, Matsushita Y, Koyano K. Relationship between the bone density estimated by cone-beam computed tomography and the primary stability of dental implants. Clin Oral Implants Res. 2012;23(7):832-6. doi: 10.1111/.1600-0501.2011.02203.x

20. Arisan V, Karabuda ZC, Avsever H,ÖZdemir T. Conventional multi-slice computed tomography (CT) and cone-beam CT (CBCT) for computerassisted implant placement. Partl: Relationship of radiographic gray density and implant stability. Clin Implant Dent Relat Res. 2013;15(6):893-906. doi: 10.1111/1.1708-8208.2011.00436.x

21. Alsabeeha NH, De Silva RK, Thomson WM, Payne AG. Primary stability measurements of single implants in the midline of the edentulous mandible for overdentures. Clin Oral Implants Res. 2010;21(5):563-6. doi: 10.1111//.16000501.2009.01890.x

22. Pagliani L, Sennerby L, Petersson A, Verrocchi D, Volpe S, Andersson P. The relationship between resonance frequency analysis (RFA) and lateral displacement of dental implants: an in vitro study. J Oral Rehabil. 2013:40(3):221-7. doi: 10.1111/joor.12024 
23. Sennerby L,Andersson P,Pagliani L, Giani C,Moretti G, Molinari M, etal. Evaluation of a novel cone beam computed tomography scanner for bone density examinations in preoperative $3 \mathrm{~d}$ reconstructions and correlation with primary implant stability. Clin ImplantDentRelat Res. 2015;17(5):844-53. doi: 10.1111/cid.12193

24. Salimov F, Tatli U, Kürkçü M, Akoğlan M, Öztunç H, Kurtoğlu C. Evaluation of relationship between preoperative bone density values derived from cone beam computed tomography and implant stability parameters: a clinical study. Clin Oral Implants Res. 2014;25(9):1016-21. doi: 10.1111/clr.12219

25. Wada M, Tsuiki Y, Suganami T, lkebe K, Sogo M, Okuno I, etal. The relationship between the bone characters obtained by CBCT and primary stability of the implants. Int J ImplantDent. 2015;(1):3. doi: 10.1186/s40729-014-0003-x
26. Valiyaparambil JV, Yamany L OrtizD, Shafer DM, Pendrys D, Freilich M, etal. Bone quality evaluation: comparison of cone beam computed tomography and subjective surgical assessment. Int J Oral Maxillofac Implants. 2012;27(5):1271-7.

27. MahP, Reeves T,McDavid W. Deriving Hounsfield units using grey levels in cone beam computed tomography. Dentomaxillofac Radiol. 2010;39(6):323-35. doi: 10.1259/dmfr/19603304

28. Razi T,Niknami M, Ghazani FA. Relationship between hounsfield unit in CT scan and gray scale in CBCT.J Dent Res Dent Clin Dent Prospects. 2014;8(2):107. doi: 10.5681/joddd.2014.019

29. Cassetta M, Stefanelli LV,Pacifici A, Pacifici L, Barbato E. How accurate is CBCT in measuring bone density? A comparative CBCT-CT in vitro study. Clin Implant Dent Relat Res. 2014;16(4):471-8. doi:10.1111/cid.12027

\section{Dr. Parisa Soltani}

\section{(Corresponding address)}

School of Dentistry, Isfahan, Iran. 